FROM DNA TO PROTEIN 


\section{From DNA to Protein The Transfer of Genetic Information}

Maria Szekely

Department of Biochemistry, Imperial College, London, UK 
(C) Maria Szekely 1980

Softcover reprint of the hardcover 1st edition 1980

All rights reserved. No part of this publication may be reproduced or transmitted, in any form or by any means, without permission

First published 1980 by

THE MACMILLAN PRESS LTD

London and Basingstoke

Associated companies in Delhi Dublin

Hong Kong Johannesburg Lagos Melbourne

New York Singapore and Tokyo

Typeset in Great Britain by

Reproduction Drawings Ltd, Sutton, Surrey

British Library Cataloguing in Publication Data

Szekely, Maria

From DNA to protein.

1. Molecular biology

I. Title

575.2'1 QH430

ISBN 978-0-333-21838-9 ISBN 978-1-349-16264-2 (eBook)

DOI 10.1007/978-1-349-16264-2

This book is sold subject to the standard conditions of the Net Book Agreement

The paperback edition of this book is sold subject to the condition that it shall not, by way of trade or otherwise, be lent, resold, hired out, or otherwise circulated without the publisher's prior consent, in any form of binding or cover other than that in which it is published and without a similar condition including this condition being imposed on the subsequent purchaser 


\section{Contents}

Acknowledgements vii

Abbreviations Used Throughout the Text viii

Introduction $\quad 1$

\section{PART 1: THE GENETIC MATERIAL}

1. The Structure of DNA and the Structure and Organisation of Genes 13

$\begin{array}{ll}\text { Size and coding potential } & 13\end{array}$

$\begin{array}{lr}\text { Isolation of genes. Physical mapping } & 17\end{array}$

$\begin{array}{ll}\text { Genetic engineering } & 23\end{array}$

$\begin{array}{ll}\text { The primary structure of DNA } & 24\end{array}$

Secondary structure of DNA $\quad 28$

Some aspects of the organisation of the genome $\quad 39$

$\begin{array}{ll}\text { The structure of chromatin } & 42\end{array}$

2. Replication of DNA $\quad 47$

$\begin{array}{ll}\text { The overall process } & 47\end{array}$

The enzymic mechanism of replication $\quad 58$

Replication of viruses with genetic material

$\begin{array}{ll}\text { other than double-stranded DNA } & 70\end{array}$

$\begin{array}{ll}\text { In vitro synthesis of specific double-stranded DNAs } & 72\end{array}$

\section{PART 2: THE TRANSCRIPT}

3. The Process of Transcription $\quad 79$

$\begin{array}{ll}\text { Some general characteristics of the transcription process } & 79\end{array}$

$\begin{array}{lr}\text { Transcription in prokaryotes } & 80\end{array}$

$\begin{array}{ll}\text { Post-transcriptional processing of RNAs in prokaryotes } & 100\end{array}$

$\begin{array}{ll}\text { Transcription in eukaryotes } & 104\end{array}$

$\begin{array}{ll}\text { Post-transcriptional processing of RNAs in eukaryotes } & 110\end{array}$

4. Nucleic Acid Sequence Determination 118

Methods of nucleotide sequence determination in RNA and DNA 118

$\begin{array}{ll}\text { Fingerprinting technique } & 120\end{array}$ 
Copying technique

Direct sequence readout techniques

\section{The Structure of Messenger RNA}

The primary structure of messenger RNA

Prokaryotic mRNAs

Eukaryotic mRNAs

Secondary structure of messenger RNA

\section{PART 3: THE SYNTHESIS OF PROTEINS}

6. The Site of Protein Synthesis: The Ribosome

The function of the ribosome

Size and subunit structure of ribosomes

The RNAs of the ribosome

The proteins of the ribosome

The topography of the ribosome

Biosynthesis of ribosomes

7. Transfer RNA: Its Role in Decoding the Message 217

$\begin{array}{ll}\text { Adaptor function of transfer RNA } & 217\end{array}$

$\begin{array}{ll}\text { Structure of tRNA } & 218\end{array}$

$\begin{array}{ll}\text { Charging of tRNA } & 226\end{array}$

$\begin{array}{ll}\text { Codon-anticodon interaction } & 228\end{array}$

$\begin{array}{ll}\text { Binding of aminoacyl-tRNA to ribosomes } & 229\end{array}$

$\begin{array}{ll}\text { Initiator tRNAs } & 232\end{array}$

tRNA in the control of protein synthesis 235

8. The Mechanism of Translation 239

$\begin{array}{ll}\text { Initiation of protein synthesis } & 240\end{array}$

The mechanism of initiation in E. coli 242

$\begin{array}{ll}\text { Initiation of translation in eukaryotes } & 248\end{array}$

The specificity of initiation $\quad 253$

$\begin{array}{ll}\text { Elongation } & 265\end{array}$

Elongation of polypeptide chains in prokaryotes 266

$\begin{array}{ll}\text { Elongation factors in eukaryotes } & 272\end{array}$

Termination of translation and release of the polypeptide chain 273

$\begin{array}{ll}\text { Modifications of the nascent protein } & 274\end{array}$ 


\section{Acknowledgements}

I am greatly indebted to scientists, colleagues and friends from all over the world for the kind help that they gave me throughout the task of writing this book.

I wish to express my gratitude to Dr F. Sanger and to colleagues in his Division at the MRC Laboratory of Molecular Biology, Cambridge, in particular to Dr G. G. Brownlee, Dr B. G. Barrell, Dr C. Milstein, Dr P. H. Hamlyn and Dr F. E. Baralle; also to Professor H. G. Wittmann and to colleagues in his Division at the MaxPlanck-Institut für Molekulare Genetik, Berlin, in particular to Dr R. Brimacombe, Dr R. A. Garrett, Dr A. R. Subramanian, Dr V. A. Erdmann, Dr K. H. Nierhaus, $\mathrm{Dr} \mathrm{K}$. Isono and Dr S. Isono. They all not only provided me with valuable material for this book in the form of reprints, preprints, photographs, etc. but also gave me the opportunity of having very fruitful discussions on recent progress in their field of research.

It is a pleasure to thank all those who kindly helped by sending me photographs for illustrations, preprints and other miscellaneous information on their research work. In this connection I wish to thank Dr G. Stöffler, Dr P. Leder, Dr M. Wu, Dr R. H. Cohn, Dr P. Sloof, Dr B. E. Griffin, Dr A. Jacobson, Dr J. A. Lake, Dr S. L. McKnight, Dr K. E. Koths, Dr D. Dressler, Professor O. L. Miller Jr, Dr D. F. Klessig, Dr B. Johnson, Mr M. J. F. Fowler, Dr A. Klug, Dr R. A. Cox, Dr A. J. Shatkin and Professor A. R. Fersht.

I am grateful for the valuable comments and advice of those who read some chapters of the manuscript, in particular to Dr F. Sanger, Dr H. Gould, Dr B. Johnson and Mrs T. Anderton.

I am also indebted to Miss M. Gordon for her help in compiling and correcting reference lists. 


\section{Abbreviations used throughout the text}

$\mathrm{MW}$, molecular weight

ss and ds (in relation to DNA or RNA), single stranded and double stranded, respectively.

A, C, G, T and U stand for nucleotides in RNA or DNA, N for an unspecified nucleotide. Only where the text leaves ambiguities in this respect are $\mathrm{d}$ and $\mathrm{r}$ used to distinguish between deoxyribonucleotides and ribonucleotides. Similarly, the position of the phosphate group ( $\mathrm{pN}$ for $5^{\prime}$ phosphorylated nucleotides and $\mathrm{Np}$ for $3^{\prime}$ phosphorylated nucleotides) is indicated only if there is special emphasis on this structure or if the text would otherwise allow ambiguous interpretation.

bp, base pairs

$\mathrm{kb}$, kilobases

cDNA, complementary DNA

r-protein, ribosomal protein

rRNA; ribosomal RNA

In the lists of references:

PNAS, Proc. natl. Acad. Sci. U.S.A.

Nature NB, Nature New Biology 